\title{
SHORT COMMUNICATION \\ Health care provider challenges for reaching Hispanic immigrants with HPV vaccination in rural Georgia
}

\author{
JS Luque', S Raychowdhury ${ }^{2}, M$ Weaver ${ }^{1}$ \\ ${ }^{1}$ Jiann-Ping Hsu College of Public Health, Georgia Southern University, Statesboro, Georgia, USA \\ ${ }^{2}$ Department of Applied Health Sciences, Indiana State University, Terre Haute, Indiana, USA
}

Submitted: 22 October 2011; Revised: 31 January 2012; Published: 26 April 2012

Luque JS, Raychowdhury S, Weaver M

Health care provider challenges for reaching Hispanic immigrants with HPV vaccination in rural Georgia Rural and Remote Health 12: 1975. (Online) 2012

Available: http://www.rrh.org.au

\section{A B S T R A C T}

Introduction: The objective of this pilot study was to understand, from the Vaccines for Children (VFC) program provider's perspective, issues relating to vaccine access and compliance for Hispanic adolescents in a rural setting.

Methods: Researchers conducted individual structured interviews with VFC providers and focus groups with Hispanic immigrant parents in rural southern Georgia.

Results: Overall, the VFC providers said that their Hispanic patients were very positive toward vaccines in general, but there were cost issues related to stocking the vaccine and reaching the Hispanic population. The focus group discussions revealed that most Hispanic parents were not aware of the existence of the humanpapilloma virus (HPV) vaccine, nor had they heard about the VFC program.

Conclusion: Numerous vaccination barriers continue to impact HPV vaccine uptake in the Hispanic immigrant population in the US South.

Key words: cancer vaccine, cervix cancer, Hispanics, HPV vaccine, humanpapilloma virus. 


\section{Introduction}

Between 2000 and 2010, the Hispanic population almost doubled in Georgia, USA, and now accounts for $8.8 \%$ of the population ${ }^{1}$. Unlike Hispanic populations in southwestern USA who have lived there for multiple generations, in Georgia, the Hispanic population consists of a higher percentage of more recent immigrants, primarily from Mexico.

The current estimated rate for completion of at least one dose of the 3 dose HPV vaccine series in Georgia is $38.6 \%$, compared with $44.3 \%$ for the entire USA ${ }^{2}$. The US federally funded Vaccines for Children (VFC) program provides free vaccines to low-income children. The VFC provider status is associated with consistent humanpapilloma virus (HPV) vaccine recommendation for early adolescents ${ }^{3}$. However, nationally, there are disparities in vaccine awareness among Whites and ethnic and racial minority groups, with Whites reporting greater awareness compared with other groups ${ }^{4,5}$.

Moreover, there are health disparities with cervical cancer incidence and mortality rates for rural populations and Hispanics in the USA ${ }^{6}$. Latinas have twice the rate of developing cervical cancer than Whites ${ }^{7}$. In addition, Hispanics have lower rates of receiving regular Pap tests and lower health insurance coverage rates than Whites ${ }^{8}$. Given that either insurance coverage to cover the cost of vaccination or eligibility for the VFC program is one of the strongest predictors for HPV vaccination, it follows that immigrant Hispanics, who have low insurance coverage rates, may be less likely to take advantage of vaccination opportunities and will continue to experience cancer health disparities ${ }^{9}$.

The objective of this pilot study was to understand issues regarding vaccine access and compliance for rural, lowincome, Hispanic adolescents of immigrant parents from the perspective of VFC providers and the parents themselves. This pilot study used qualitative methods to explore HPV vaccine access barriers for Hispanic adolescents by interviewing VFC providers and Hispanic immigrant parents in rural southern Georgia, USA.

\section{Methods}

\section{Study sample}

Individual structured interviews were conducted with VFC providers. The providers were practicing in a rural Georgia state health district (Fig1) and identified through a VFC provider list. Also conducted were two focus groups with Hispanic immigrant parents - mothers and fathers separately - of girls aged 9-18 years, aided by a local Hispanic-serving non-profit organization.

\section{Study instruments and recruitment}

For both the interview questions and the focus group guide, the researchers used instruments developed in a previous study which demonstrated credibility and face validity ${ }^{10}$. The 8 question structured interview instrument contained open-ended questions about common health topics discussed with patients, challenges with vaccine administration, Hispanic beliefs and attitudes toward the HPV vaccine, and the role of outreach and health education to improve vaccination rates. The 14 question focus group guide contained questions about knowledge of cervical cancer and the HPV vaccine, health-seeking behavior regarding vaccinations, barriers and benefits, and access and sources of health information. The focus group guide was translated into Spanish, and the groups were facilitated by a native Spanish speaker.

Beginning with a comprehensive list of 29 VFC providers, introduction letters were sent, followed by phone calls to recruit and schedule individual interviews with the providers either in person or via telephone. Recruitment efforts were ceased after three failed recruitment attempts. To recruit parents to the focus groups, only recruitment with the assistance of the Hispanic-serving non-profit was successful, which directly contacted participants and invited them to attend the focus group. 


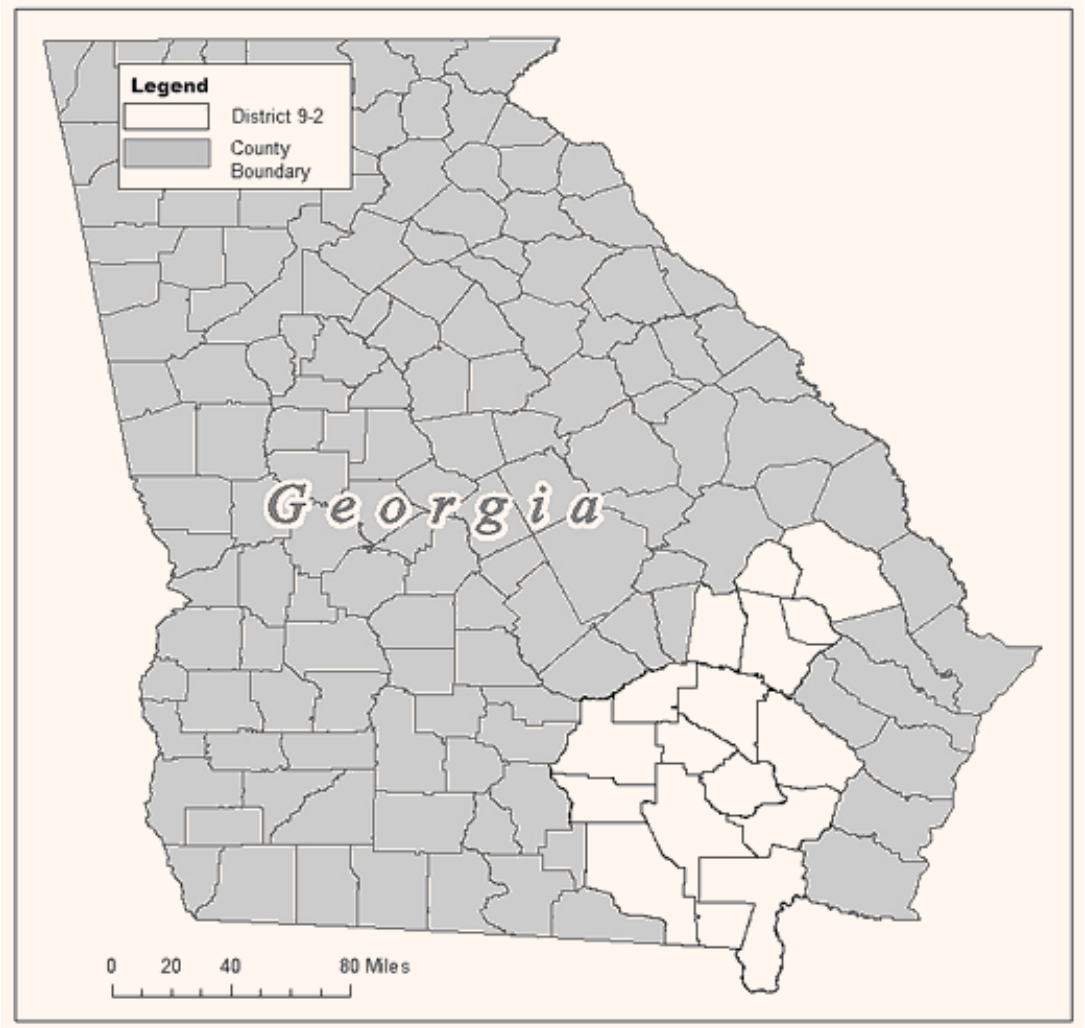

Figure 1: Rural Georgia state health district.

In response to an issue raised in the ethical review process, the importance of maintaining confidentiality after leaving the session was explained to focus group participants. All participants completed informed consent documents and received a US\$10 stipend.

\section{Data analysis}

All interviews were digitally recorded and transcribed. Content analysis was used to code transcripts using a codebook based on social marketing conceptual categories to understand behaviors related to the HPV vaccine (barriers, benefits, product, price, place, and promotion), and containing 28 sub-codes. Pairs of coders coded transcripts independently using MAXQDA qualitative data analysis software (www.maxqda.com) and then compared with coded transcripts to improve reliability and consistency. The coders met to resolve inconsistencies, and then recoded transcripts either with the same refined code or a new code to improve reliability. For example, under the parent code of barriers, one of the coders identified language barriers for Hispanic patients as a potential new code. However, after reaching consensus, it was agreed that the quotes could be covered under the code for 'low English proficiency'.

\section{Ethics approval}

The study was approved by the Georgia Southern University institutional review board (approval no. H11035) prior to data collection.

\section{Results}

Participant characteristics of the two focus groups (mothers and fathers separately) and VFC providers are listed (Table 
1). The sample of eight VFC providers included nurse practitioners, nurse managers, registered nurses, physician assistants, and one physician. The sample represented seven ZIP codes in the state health district. Interviews with VFC providers identified numerous barriers to delivering the HPV vaccine to Hispanic adolescents including: (i) low English proficiency of the parents; (ii) Medicaid reimbursement shortfalls; (iii) difficulty in completing the 3-dose HPV vaccine series with a mobile population; (iv) lack of transportation access; and (v) lack of knowledge and misperceptions about the HPV vaccine. One provider stated:

There's a communication gap with those patients. Like, if I get 10 Hispanic patients, almost 6 won't understand English; 4 will understand a little bit at least, I can tell them something about diet, or vaccines.

Overall, the VFC providers expressed that Hispanic patients were very positive toward vaccines, but there were cost issues for the provider, related to stocking the vaccine and reaching the population, since providers in many cases may have limited contact with adolescent patients, who do not routinely seek healthcare services.

The two focus group discussions with mothers and fathers revealed that most Hispanic parents were not aware of the HPV vaccine, nor the VFC program. One mother said that the schools should promote the vaccine to increase access and awareness. Another mother believed that a patient needed to see a gynecologist before receiving the vaccine. Fathers were mostly unaware of the HPV vaccine, compared with mothers. However, both mothers and fathers expressed positive views toward childhood vaccinations. There were exceptions, however. For example, one mother believed that if her daughter received the vaccine, she might pursue sexual relations with multiple partners as a consequence. The parents identified numerous barriers to HPV vaccination for their daughters including: (i) undocumented status preventing access; (ii) fear of not knowing about cancer; (iii) cultural issues, especially related to diseases caused by sexual behaviors; (iv) low English proficiency; (v) lack of information; and (vi) distrust of particular healthcare facilities. Illustrative quotes from the VFC provider interviews and parent focus groups are organized and presented by thematic code (Table 2 ).

\section{Discussion}

Hispanic subgroups vary according to their HPV awareness and knowledge as a function of acculturation and socioeconomic status ${ }^{11,12}$. Recent studies have found that certain Hispanic subgroups have more favorable beliefs and attitudes toward the HPV vaccine and higher completion rates $^{13,14}$. Increasing HPV vaccination rates for Hispanic adolescents is an important public health priority because Hispanic women have been found to have high incidence and mortality rates from cervical cancer compared with other groups for multiple reasons, including lack of a regular healthcare provider and convenient access to timely screening and follow up ${ }^{15}$.

Further research is needed to design interventions which increase Hispanic parental awareness and knowledge of HPV vaccine availability, and to decrease the barriers to adolescent vaccinations. A large proportion of the Hispanic population living in this area of rural Georgia works in low wage occupations, such as farm labor. Such occupations do not include health insurance benefits, so healthcare providers might wrongly assume that many of their Hispanic patients do not work because they do not have insurance. Language barriers and lack of insurance coverage were listed by both VFC providers and parents as preventing access to health information and health services. Therefore, the provision of professional medical translation services is one priority area to address to ensure that parents receive information in Spanish from a healthcare provider about programs such as the VFC to provide the HPV vaccine at no cost for their vaccine-eligible children. Moreover, health behavior change programs geared toward Hispanic immigrant populations must address the issue of trust in healthcare institutions, as well as cultural barriers to engaging in preventive healthcare practices, including sexually transmitted infections. In addition, policy changes at the state level, such as HPV vaccine mandates for school entry, are both acceptable to Hispanic parents and the most likely upstream approach to increase overall HPV vaccination rates ${ }^{16}$. 
Table 1: Demographics of focus group participants and healthcare providers

\begin{tabular}{|c|c|c|c|}
\hline \multirow[t]{2}{*}{ Demographic } & \multicolumn{2}{|c|}{$\begin{array}{c}\text { Focus group participants } \\
\text { n (\%) }\end{array}$} & \multirow{2}{*}{$\begin{array}{c}\text { Healthcare } \\
\text { providers } \\
\text { n }(\%) \\
(\mathbf{n}=8)\end{array}$} \\
\hline & $\begin{array}{l}\text { Mothers } \\
(\mathrm{n}=5)\end{array}$ & Fathers $(n=7)$ & \\
\hline \multicolumn{4}{|l|}{ Age (years) } \\
\hline $25-34$ & $3(60)$ & $5(71)$ & $1(12)$ \\
\hline $35-44$ & $2(40)$ & $2(29)$ & 0 \\
\hline $45-54$ & 0 & 0 & $6(75)$ \\
\hline $55-64$ & 0 & 0 & $1(12)$ \\
\hline $\begin{array}{l}\text { Age of vaccine eligible child } \\
\text { (average; range) }\end{array}$ & $\begin{array}{c}12.7 \\
(10-18)\end{array}$ & $\begin{array}{c}12.8 \\
(9-18)\end{array}$ & NA* \\
\hline \multicolumn{4}{|l|}{ Marital status } \\
\hline Married/living together & $4(80)$ & $7(100)$ & NA \\
\hline Divorced & $1(20)$ & 0 & NA \\
\hline \multicolumn{4}{|l|}{ Country of birth } \\
\hline Mexico & $5(100)$ & $6(86)$ & NA \\
\hline Honduras & 0 & $1(14)$ & NA \\
\hline \multicolumn{4}{|l|}{ Household income/week } \\
\hline$<\$ 200$ & $1(20)$ & $3(43)$ & 0 \\
\hline$\$ 200-\$ 349$ & $2(40)$ & $1(14)$ & 0 \\
\hline$\$ 350-\$ 449$ & $2(40)$ & $2(29)$ & 0 \\
\hline$>\$ 450$ & 0 & $1(14)$ & $8(100)$ \\
\hline \multicolumn{4}{|l|}{ Education } \\
\hline$<$ High school & $1(20)$ & $3(43)$ & 0 \\
\hline High school & $3(60)$ & $4(67)$ & 0 \\
\hline$>$ High school & $1(80)$ & 0 & $8(100)$ \\
\hline Years in USA (range) & $10.8(4-15)$ & $11.9(5-16)$ & NA \\
\hline \multicolumn{4}{|l|}{ Employment } \\
\hline Years in current job (range) & NA & NA & $8(0.5-16)$ \\
\hline
\end{tabular}

\section{Limitations}

As a small pilot study, there were several limitations. The sample size was small because of recruitment challenges for both the parent focus groups and the VFC provider interviews, possibly related to the new Georgia antiimmigration law, as well as media-driven controversy surrounding the HPV vaccine. While alternative recruitment strategies were attempted to recruit two additional parent focus groups (eg flyers at community meetings and Mexican grocery stores), these efforts were ultimately unsuccessful. For the VFC provider interviews, resistance to participation was encountered from some health department affiliated providers who stated their employment situation prevented them from participation in research activities. It was not possible to determine the reason for this excuse since some other health department affiliated providers agreed to participate in the interviews. Nevertheless, participants provided data indicating that numerous barriers exist and ultimately impact HPV vaccine uptake among Hispanic adolescents. 
Table 2: Thematic codes and quotes from healthcare provider interviews and parent focus groups

\begin{tabular}{|c|c|}
\hline $\begin{array}{l}\text { Theme/topic } \\
\text { (origin) }\end{array}$ & Illustrative quotes \\
\hline \multicolumn{2}{|l|}{ Barriers } \\
\hline $\begin{array}{l}\text { Lack of } \\
\text { transportation }(\mathrm{HP})\end{array}$ & $\begin{array}{l}\text { "Because, for them if they don't drive or if they don't have the ability to get themselves back and forth, they are } \\
\text { having to pay other people to transport them back and forth to my practice. Actually, I became aware that there } \\
\text { were some situations where they were really being taken advantage of in a bad way." (HP) }\end{array}$ \\
\hline $\begin{array}{l}\text { Immigration status } \\
(\mathrm{HP})\end{array}$ & $\begin{array}{l}\text { "There are concerns if I had undocumented Hispanic patients, there were grave concerns about not being paid and } \\
\text { coming into a public setting to get health care." (HP) }\end{array}$ \\
\hline $\begin{array}{l}\text { Lack of health } \\
\text { insurance (HP) }\end{array}$ & $\begin{array}{l}\text { "I think is more or less the patients that we see in community health care settings, and you know, you have the } \\
\text { patients that are uninsured, so that goes back to you know, basically them never have even worked a job, to be } \\
\text { offered this opportunity, you know, to be insured. And sometimes just the fact that is the premium is so high that } \\
\text { they can't afford it, but most of our patients that come to our community health care centers are patients that on } \\
\text { a lower level with learning." (HP) }\end{array}$ \\
\hline $\begin{array}{l}\text { Low English } \\
\text { proficiency (HP) }\end{array}$ & $\begin{array}{l}\text { "Another miscommunication with Hispanic patients is that sometimes the interpreter is the patient itself. The } 14 \\
\text { year-old, let's say, the mother doesn't know English, you can't explain to her and then she explains to the } \\
\text { mother. So that's one drawback, unless they come with their aunts etc. Most of the time we will have a } 9 \text { year- } \\
\text { old comes and expresses about a } 2 \text { year-old's complaints. Just like a } 14 \text { year-old comes for a vaccine. She's } \\
\text { interpreted to the mother about getting approval for getting a vaccine." (HP) }\end{array}$ \\
\hline $\begin{array}{l}\text { Migrant living } \\
\text { patterns (HP) }\end{array}$ & $\begin{array}{l}\text { "In follow up we were talking } 6 \text { months to get vaccine series in and the population is so mobile that keeping } \\
\text { contact is difficult ... I probably lose more than I keep as far as maintaining some type of follow up." (HP) }\end{array}$ \\
\hline $\begin{array}{l}\text { Lack of information } \\
\text { on HPV vaccine } \\
(\mathrm{HP}, \mathrm{FG})\end{array}$ & $\begin{array}{l}\text { "The same way with the vaccines, if they don't hear from somebody in their culture that it's okay to take it ... But } \\
\text { a lot of times if it's an older person that has just their mind set that "Oh no this is something that they are injecting } \\
\text { in me, I am being a test patient or a guinea pig", it will not happen. And they really rely a lot on their husbands to } \\
\text { say is OK because he comes from that same culture that it's not something that has been approved from a doctor } \\
\text { in their community ... But if you have a Hispanic lady that come in, and that she is educated or you know, she } \\
\text { does something other than field work or has gotten out of the field work and has been informed about these } \\
\text { things, she is more than likely to take it; but if it's somebody more or less a field worker their culture beliefs are } \\
\text { totally different." (HP) } \\
\text { "Sometimes they explain it to you and you don't understand it, and they already explained it to you, but you } \\
\text { don't understand it." (Mother) }\end{array}$ \\
\hline $\begin{array}{l}\text { Need information } \\
\text { about HPV vaccine } \\
(\mathrm{HP}, \mathrm{FG})\end{array}$ & $\begin{array}{l}\text { "Well, the general concern or questions is that does it cause cervical cancer. A lot of the teenagers that are that } \\
\text { age will ask me that question. You know, does it cause you to get HPV? Does it cause you to get cervical cancer? } \\
\text { Those are probably the only ... the biggest questions other than does it hurt just as a teenager you, know or } \\
\text { whatever, is the shot gonna hurt?" (HP) } \\
\text { "Yes, because the truth I think that if those of us that are here don't know and we want to know what this is and I } \\
\text { don't know if all human beings have that disease, we don't know ... and if that is the prescription for the ones } \\
\text { that follow then it would be good." (Father) }\end{array}$ \\
\hline $\begin{array}{l}\text { Misperceptions } \\
\text { about HPV vaccine, } \\
\text { cultural factors (HP, } \\
\text { FG) }\end{array}$ & $\begin{array}{l}\text { "They think that if they are not having sex they don't need the vaccine. Instead of looking at it as a preventive } \\
\text { measure. Instead of I'm not doing anything to get it so I won't get it." (HP) } \\
\text { "In general, the majority doesn't know about this type of disease or because among Latinos it is more difficult to } \\
\text { talk about this type of problem.” (Father) } \\
\text { "They die for sadness of telling other people what it is they have. There are a lot of people that do like that. That } \\
\text { they hide it form their own family, 'I am embarrassed for my family - that others hear of it.' And as I say, they } \\
\text { cover their mouth to not say anything to other people. But it is a serious disease sometimes and they don't want } \\
\text { to say or don't want to look for help. The majority is like that." (Father) }\end{array}$ \\
\hline \multicolumn{2}{|l|}{ Benefit } \\
\hline $\begin{array}{l}\text { Vaccines, in } \\
\text { general, are viewed } \\
\text { positively (HP) }\end{array}$ & "For vaccines in general, they are always real receptive of vaccines and that includes the HPV." (HP) \\
\hline $\begin{array}{l}\text { Mother/daughter } \\
\text { communication } \\
\text { (HP) }\end{array}$ & $\begin{array}{l}\text { "Mothers think because this isn't a new disease, but it's not something that mothers dealt with when they are } \\
\text { teenagers. So I don't think that mothers understand the risk and the consequences. So therefore, they don't } \\
\text { perceive it as a need because ... a girl may not ask her mom about how they are going to have sex. But when it } \\
\text { comes to a shot, 'Oh I can ask my mom about that'. Well I wish you would've asked before you had sex with } \\
\text { someone who you didn't even know what his name is!” (HP) }\end{array}$ \\
\hline
\end{tabular}




\section{Table 2: cont'd}

\begin{tabular}{|c|c|}
\hline $\begin{array}{l}\text { Keep healthy (HP, } \\
\text { FG) }\end{array}$ & $\begin{array}{l}\text { "You know, thank goodness a lot of our children even within the Hispanic population are on Medicare, } \\
\text { Peachcare, so they get their yearly health checks, yearly physicals, and of course the schools require } \\
\text { immunizations so they get their regular immunizations through their yearly health checks and at that time." (HP) } \\
\text { "Health, to protect oneself, prevent in the future a disease like that." (Mother) }\end{array}$ \\
\hline \multicolumn{2}{|l|}{ Costs } \\
\hline Money (HP) & $\begin{array}{l}\text { "Primarily because of the cost factor and not just to them but for us, the cost of carrying the vaccine. So it's kind } \\
\text { of a two-way problem. It costs us a lot to purchase it upfront and keep it and then we have to generate payment } \\
\text { for the vaccine when we administer it. Or we're out our costs, so it's kind of hard both ways." (HP) } \\
\text { "It seems like we tend to get left out of the loop sometimes with the bigger communities to get some funding and } \\
\text { when it drills down to us, there's not much left. And there's definitively a need with our population here in the } \\
\text { schools, over } 40 \% \text { Hispanic, there's definitely a need." (HP) }\end{array}$ \\
\hline $\begin{array}{l}\text { Risk of premarital } \\
\text { sex }(H P, F G)\end{array}$ & $\begin{array}{l}\text { "I think the Hispanic population is less lenient towards their teenage girls ... we know she's gonna be sexually } \\
\text { active, we know she's gonna be with lots of guys so let's get this Gardasil. They are more thinking let's hope that } \\
\text { she waits until she gets married. I mean they are actually thinking that which is different from our other local } \\
\text { populations." (HP) } \\
\text { "If I give it to my daughter they will think that with that they can have relationships with various partners." } \\
\text { (Mother) }\end{array}$ \\
\hline $\begin{array}{l}\text { Side-effects (HP, } \\
\text { FG) }\end{array}$ & $\begin{array}{l}\text { "But then also, educating their parents to say that there are no harmful effects, we have good data showing safety } \\
\text { and efficacy and just encouraging more awareness that it is a good vaccine and the consequences are extremely } \\
\text { costly - both emotionally and physically." (HP) } \\
\text { "What if it has consequences, what if she is allergic to that?" (Mother) }\end{array}$ \\
\hline \multicolumn{2}{|l|}{ Place } \\
\hline $\begin{array}{l}\text { Fear and dislike of } \\
\text { healthcare facilities } \\
(\mathrm{HP}, \mathrm{FG})\end{array}$ & $\begin{array}{l}\text { "I know that these patients can get a vaccine at the Health Department but they don't want to go to the Health } \\
\text { Department. There are some will go, there are some that are comfortable going but a lot of people who come to } \\
\text { the office to be seen because they don't want to go the Health Department." (HP) } \\
\text { "But for us, well to give an example, who I would say, in the Health Department, but there's not much trust." } \\
\text { (Mother) }\end{array}$ \\
\hline \multicolumn{2}{|l|}{ Promotion } \\
\hline $\begin{array}{l}\text { Doctor's } \\
\text { recommendation } \\
(\mathrm{HP}, \mathrm{FG})\end{array}$ & $\begin{array}{l}\text { As far as Gardasil [vaccine for prevention of four types of HPV] , I've discussed Gardasil with, unless the patient is } \\
\text { pregnant, with just my regular GYN patients, I discuss Gardasil at their annual physical, for people under the age } \\
\text { of } 27 \text {. Every patient that I see for a physical, they are given a handout on HPV and Gardasil to be reviewed before } \\
\text { I come in the room and my nurse actually questions the patient about it and answers any questions. When I come } \\
\text { in, I look at he notes that she's written because she will write declines Gardasil or has questions or whatever. So I } \\
\text { answer any questions the patient has and I'll try to encourage people as much as possible to get the vaccine." (HP) } \\
\text { "The children have their own doctor, their pediatrician. Well most of the time they are there and one makes an } \\
\text { appointment to take them. There is where I have trust to tell him how my daughter is because he's the one that } \\
\text { knows. He's the one we can trust and ask what benefits this vaccine has for our children. In him we trust because } \\
\text { he is the doctor and he knows." (Father) }\end{array}$ \\
\hline $\begin{array}{l}\text { Internet and other } \\
\text { media outlets } \\
(\mathrm{TV} / \text { Radio) }(\mathrm{HP})\end{array}$ & $\begin{array}{l}\text { "I will tell you when the commercials first started coming on about cervical cancer, in the more of the } \\
\text { advertisements on TV and everything else, we did get more questions about that. You know calling from people } \\
\text { that weren't even our patients that were calling in asking if we had the vaccine." (HP) }\end{array}$ \\
\hline $\begin{array}{l}\text { Educational } \\
\text { materials and } \\
\text { brochures }(\mathrm{HP}, \mathrm{FG})\end{array}$ & $\begin{array}{l}\text { "We give an information sheet about each vaccine that we give. A big sheet that has side-effects, who should get } \\
\text { it. You know, this kind of thing that we give with each shot that we give." (HP) } \\
\text { "It is an important help for the person, to motivate them to get informed and that they understand that it is a } \\
\text { benefit for them." (Father) }\end{array}$ \\
\hline Schools (HP, FG) & $\begin{array}{l}\text { "So, I think we are going to look at more getting the vaccine to them and the schools, that makes sense to me. } \\
\text { And maybe if there are other community groups that coordinate and put together health fairs and things like that } \\
\text { for the migrant population anyway that we could maybe should look at them to see about vaccinating and } \\
\text { including that in the programs." (HP) } \\
\text { "Or even the school itself sends forms that this and this vaccine is available or even the 'flu shot. Why do they } \\
\text { make a big deal about 'summer is here take your kids, make sure they have the 'flu shot.' Why isn't that done } \\
\text { with this, which I think is even more important?" (Mother) }\end{array}$ \\
\hline
\end{tabular}




\section{Conclusion}

This study highlights the similarities in and differences between HPV vaccination barriers as perceived by VFC providers and Hispanic parents related to vaccinating Hispanic adolescents. The qualitative findings further explain quantitative results from a survey study of Georgia VFC providers which found that insufficent insurance coverage was the major barrier for not vaccinating adolescents, and that major predictors for not recommending the vaccine to 11-12 year old girls included parental barriers, such as reluctance to discuss sexuality and lack of education ${ }^{17}$. Barriers to HPV vaccination remain a major challenge for Hispanic immigrant parents who have limited contact with the healthcare system. The results of this study will be used to inform future quantitative research with Hispanic parents to develop a social marketing plan to increase HPV vaccination rates for adolescent Hispanics in rural southern Georgia.

\section{Acknowledgments}

Dr Luque received a Georgia Southern University internal grant to support this project. The authors thank Voces Unidas for assisting with the focus group recruitment and hosting the groups. Also thanked are Angela Rodriguez and Daniela Hazelwood for their assistance with data collection, transcribing, translating and coding.

\section{References}

1. US Census Bureau. United States Census 2010. (Online) 2010. Available: http://www.census.gov (Accessed 2 October 2011).

2. Centers for Disease Control and Prevention. FDA licensure of quadrivalent human papillomavirus vaccine (HPV4, Gardasil) for use in males and guidance from the Advisory Committee on Immunization Practices (ACIP). Morbidity and Mortality Weekly Report (MMWR) 2010; 59: 630-632.
3. Vadaparampil ST, Kahn JA, Salmon D, Lee JH, Quinn GP, Roetzheim $\mathrm{R}$ et al. Missed clinical opportunities: provider recommendations for HPV vaccination for 11-12 year old girls are limited. Vaccine 2011; 29(47): 8634-8641.

4. Hughes J, Cates JR, Liddon N, Smith JS, Gottlieb SL, Brewer NT. Disparities in how parents are learning about the Human Papillomavirus Vaccine. Cancer Epidemiology, Biomarkers, and Prevention 2009; 18(12): 363-372.

5. Cui Y, Baldwin SB, Wiley DJ, Fielding JE. Human Papillomavirus Vaccine among adult women: disparities in awareness and acceptance. American Journal of Preventive Medicine 2010; 39(6): 559-563.

6. Yabroff KR, Lawrence WF, King JC, Mangan P, Washington KS, Yi B et al. Geographic disparities in cervical cancer mortality: what are the roles of risk factor prevalence, screening, and use of recommended treatment? Journal of Rural Health 2005; 21(2): 149157.

7. US Cancer Statistics Working Group. United States Cancer Statistics: 1999-2007 Incidence and Mortality Web-Based Report. Atlanta, GA: Department of Health and Human Services, Centers for Disease Control and Prevention, and National Cancer Institute, 2010.

8. Flores K, Bencomo C. Preventing cervical cancer in the Latina population. Journal of Women's Health (Larchment) 2009; 18(12): 1935-1943.

9. Drewry J, Garces-Palacio IC, Scarinci I. Awareness and knowledge about Human Papillomavirus among Latina immigrants. Ethnicity and Disease 2010; 20: 327-333.

10. Luque JS, Castañeda H, Martinez Tyson D, Vargas N, Meade CD. Formative research on HPV vaccine acceptability among Latina farmworkers. Health Promotion Practice 2011; http://www.ncbi. nlm.nih.gov/pubmed/21881079 (in press). 
11. Kobetz E, Kornfeld J, Vanderpool RC, Finney Rutten LJ, Parekh N, O’Bryan G et al. Knowledge of HPV among United States Hispanic women: opportunities and challenges for cancer prevention. Journal of Health Communication 2010; 15(Suppl3): 2229.

12. Luque JS, Castañeda H, Tyson DM, Vargas N, Proctor S, Meade CD. HPV awareness among Latina immigrants and Anglo American women in the southern U.S.: cultural models of cervical cancer risk factors and beliefs. NAPA Bulletin 2010; 34(1): 84-104.

13. Lechuga J, Swain GR, Weinhardt LS. The cross-cultural variation of predictors of human papillomavirus vaccination intentions. Journal of Women's Health 2011; 20: 225-230.

14. Yeganeh N, Curtis D, Kuo A. Factors influencing HPV vaccination status in a Latino population; and parental attitudes towards vaccine mandates. Vaccine 2010; 28(25): 4186-4191.
15. Scarinci IC, Garcia FA, Kobetz E, Partridge EE, Brandt HM, Bell L et al. Cervical cancer prevention: new tools and old barriers. Cancer 2010; 116(11): 2531-2542.

16. Robitz R, Gottlieb SL, De Rosa CJ, Guerry SL, Liddon N, Zaidi A et al. Parent attitudes about school requirements for human papillomavirus vaccine in high-risk communities of Los Angeles, California. Cancer Epidemiology, Biomarkers, and Prevention 2011; 20(7): 1421-1429.

17. Dixon ET. An assessment of HPV vaccination among Georgia physicians: knowledge, barriers, supports, practices, and adherence to ACIP guidelines and recommendations (Thesis). Statesboro, GA: Georgia Southern University, 2011. 